\title{
Safety Aspects in Tissue Banking - An Update
}

\author{
Axel Pruß Jan Schroeter \\ University Tissue Bank, Institute of Transfusion Medicine, Charité - Universitätsmedizin Berlin, Berlin, Germany
}

Tissue transplants are of continuing high importance for patient care. As with all transplanted material of human origin, tissue transplants carry risks of disease transmission which must be controlled by the application of stringent donor selection criteria and comprehensive quality systems. On the one hand, against the background of an ageing population in Europe, there is an increasing need for tissue transplants. On the other hand, there is already a relative shortage for many tissue transplants. It is therefore necessary to define donor selection criteria carefully but also critically. In particular, the maximum acceptable post-mortem time interval is an important parameter here.

In the present special issue, some of these currently discussed questions were investigated and proposals for scientific-based answers provided.

Serological or molecular genetic tests for infectious diseases (HIV, hepatitis B and C) are mandatory and are carried out routinely. In some cases, post-mortem blood is the only available sample for the diagnostic. Although a large number of the laboratory tests used today have been validated for post-mortem blood, a characterization of the blood samples used for this purpose is not yet defined. Larscheid et al. [1] have therefore examined the immunoglobulin $\mathrm{G}$ ( $\mathrm{IgG}$ ) content in the post-mortem blood of tissue donors in comparison with the value of the ante-mortal blood sample. The total IgG values in antemortal samples were below the lower limit of $6 \mathrm{~g} / \mathrm{l}$ in $20 \%$ of the cases. Additionally, the total IgG was also significantly lower in the post-mortem samples compared to the ante-mortal samples. A correlation with the post-mortem time could not be found. Low IgG levels could therefore limit the validity of post-mortem blood for infection serological tests. The findings underline the importance of additional NAT tests.

For tissues that cannot undergo a sterilization process, e.g. corneal transplants, microbiological safety plays an essential role in protecting the recipient. Here, sensitive testing methods and a risk-adapted testing strategy are essential. The European Pharmacopoeia provides detailed guidelines, but their specific implementation in tissue banks was and is the subject of scientific studies. Herrlinger et al. [2] investigated in the presented validation study different incubation temperatures in a semi-automated system with blood culture bottles. $35^{\circ} \mathrm{C}$ showed to be the incubation temperature with the fastest growth of the majority of the test strains used and a complete detection within 14 days. It is important for tissue banks to optimize their microbiological testing strategies for human pathogenic microorganisms, but also for potentially pathogenic contaminants in the context of tissue explantation. This is not without problems, as sensitive semiautomated systems for low incubation temperatures between 20 and $25^{\circ} \mathrm{C}$ are not available. Given the large spectrum of tissue transplants available, further studies on this topic will certainly be useful in the future.

The realization of tissue donations is bonded to a tight timeframe. Depending on the type of tissue, deadlines are set to prevent a loss of tissue quality with increasing time intervals. According to the applicable regulations (EDQM guidelines, Guidelines of the German Medical Association), corneas must be explanted within $72 \mathrm{~h}$ after death. Hofmann et al. [3] asked themselves whether this time interval has an influence on the quality of the transplant-
(C) 2021 The Author(s)

Published by S. Karger AG, Basel

This is an Open Access article licensed under the Creative Common Attribution-NonCommercial-4.0 International License (CC BY-NC) (http://www.karger.com/Services/OpenAccessLicense), applicable to the online version of the article only. Usage and distribution for commercial purposes requires written permission. 
ed tissue. They examined 21,454 database entries from corneal donations in the period from 2014 to 2018. The result shows that a time interval of up to $72 \mathrm{~h}$ for corneal tissue is acceptable from the point of view of tissue quality and had no negative influence on the outcome of the transplanted corneas.

In addition to a careful medical history and a physical examination, comprehensive serological and molecular screening of the tissue donors for relevant viral markers from blood for HIV, HBV and HCV is required. Pruß et al. [4] describe in detail in their article that clear decisions have to be made regarding follow-up tests and criteria for tissue release, especially with reactive results. With HBV and HCV tests, a highly sensitive virus genome test should play a central role in the diagnosis, especially if the serology is unclear. Based on the clinical relevance of the specific virus markers, the sensitivity of the serological and molecular biological methods used and the application of inactivation methods, the authors developed algorithms for tissue release. New therapeutic approaches for $\mathrm{HCV}$ infected donors could play an increasing role in the assessment of reactive anti-HCV findings.
We think that the results of the presented papers provide important contributions and recommendations for the further development of useful standards to ensure safety and quality in tissue banking. Finally, it should be noted that the European Commission announced for 2021 a revision of the blood, tissues and cells legal framework, including Directive 2004/23/EC on safety and quality of human tissues and cells and their implementing acts.

According to the Commission, this REFIT (revision of the blood, tissues and cells legislation) initiative aims to update the current legislation to allow for a more flexible alignment to scientific and technological developments. It aims to address the re-emergence of communicable diseases, including lessons learned from the coronavirus pandemic, as well as the increasing commercialization and globalization of the sector. With the revision, many technical provisions would be removed, which could allow a rapid updating of standards $[5,6]$. The content of the current EDQM guide to the quality and safety of tissues and cells for human application should mandatorily serve as the basis for this revision initiative as well [7].

\section{References}

1 Larscheid G, Schulz T, Herbst H, Trögel T, Eulert S, Pruß A, et al. Comparison of total immunoglobulin $\mathrm{G}$ in ante- and postmortem blood samples from tissue donors. Transfus Med Hemother. 2021;(1):https://doi.org/ $10.1159 / 000513662$.

2 Herrlinger F, Schulz T, Pruß A, Schulz E. Validation of microbiological testing of tissue preparations with different incubation temperatures. Transfus Med Hemother. 2021;(1): https://doi.org/10.1159/000513646.
3 Hofmann N, Wittmershaus I, Salz AK, Börgel $\mathrm{M}$. Cornea procurement and processing up to 72 hours: no risk for cornea transplant quality. Transfus Med Hemother. 2021;(1):https:// doi.org/10.1159/000510588.

4 Pruß A, Chandrasekar A, Sánchez-Ibáñez J, Lucas-Samuel S, Kalus U, Rabenau HF. Algorithms for the testing of tissue donors for human immunodeficiency virus, hepatitis B virus, and hepatitis $\mathrm{C}$ virus. Transfus $\mathrm{Med} \mathrm{He-}$ mother. 2021;(1):https://doi.org/10.1159/ 000513179.
5 https://ec.europa.eu/info/publications/2021commission-work-programme-key-documents_en.

6 https://ec.europa.eu/health/sites/health/files/ blood_tissues_organs/docs/swd_2019_376_ en.pdf.

7 European Directorate for the Quality of Medicines and HealthCare of the Council of Europe (EDQM). Guide to the quality and safety of tissues and cells for human application. 4th ed. Council of Europe; 2019. 